\title{
ENVIRONMENTAL WORLDVIEW: A CASE STUDY OF YOUNG PEOPLE FROM KOSOVO
}

\author{
Mile Srbinovski, Leonora Çarkaj, Murtezan Ismaili \\ Faculty of Contemporary Sciences and Technologies \\ South East European University, Tetovo, North Macedonia \\ m.srbinovski@seeu.edu.mk ; lc26141@seeu.edu.mk ; murtezan.ismaili@seeu.edu.mk
}

\begin{abstract}
Understanding attitudes towards the environment is important because they often determine behaviour that either increases or decreases environmental quality. In this article we investigate the environmental worldview of the young people from Kosovo. The New Revised Environmental Paradigm Scale or New Ecological Paradigm Scale, known as NEP Scale (Dunlap et al., 2000) was used. The study involved 330 young people age 18-20. 150 young people are from secondary schools, and other (180) are from some different faculties at the State University in Mitrovica. The mean score for the full NEP scale in this study was 3.48, which indicates a low endorsement of the NEP among the sample of Kosovo young people. The averages of the sub-dimensions varied between 3.08 ("Limits to growth") and 3.73 ("Ecocrisis"). Like as others non-industrialized societies, young people from Kosovo tend to believe in the profound connection between humanity and nature, or there are no clear differences between pro-NEP and pro-DSP views. This study confirms the thesis that environmental worldviews differ across cultures. The mean value of the NEP Scale can be feasibly associated with various variables concerning general environmental attitudes. In order to discover the factors that create a pro-ecological orientation of young people in this country, additional researches are needed.
\end{abstract}

Key words: worldview, young people, NEP scale, Mitrovica, Kosovo. 


\section{INTRODUCTION}

Environmental education is a developing process of active learning in which individuals and groups acquire the necessary knowledge, understanding, attitudes and skills for a determined, motivated, responsible, and above all, joint action towards obtaining and maintaining a dynamic balance in the environment (Srbinovski, 2005a, 2005b). In this definition are included all the essential components (attitudes, awareness, knowledge, skills and action) of environmental literacy as the ultimate goal of environmental education. According to our opinion, in the late twentieth century some widely-accepted rooted values, attitudes, and beliefs were the source of ecological problems.

Environmental worldview can be defined as "the collective beliefs and values that give people a sense of how the world works, their role in the environment, and right and wrong behavior toward the environment. Environmental worldviews dictate how we interact with nature and our attitude toward how we use the natural resources it contains" (Gillaspy, 2015: 1).

Studies of environmental views come from a wide variety of fields. Social scientists are motivated to study environmental concern because if we are to move towards environmental sustainability, we need to better understand the environmental worldviews that influence resource consumption and pollution (Castro, 2006: 248).

There are many scales that can measure the attitudes and concerns of groups of people regarding environmental issues (Maloney, Ward and Brauch, 1975; Weigel and Weigel, 1978; Wiesman \& Bogner, 2003). A widely used measure of environmental worldview is Dunlap and Van Liere's New Environmental Paradigm (NEP) scale, first published in 1978. Previous scales focused on environmental attitudes and concerns regarding problem specifics such as pollution and misuse of natural resources (Iozzi, 1981). The scale was revised by Dunlap et al. (2000) and became the New Ecological Paradigm Scale. The revised NEP scale appears to be an improved measuring instrument compared to the original version since the first point (1) offers much more complete coverage of the main aspects of an ecological worldview: the reality of growth constraints, anti-anthropocentrism, fragility of nature, balance, rejection (2) avoids the lack of fat-free balance in the direction of the article of the original scale (where only four articles, all related to anthropocentrism, have been declared in an anti-NEP direction as well as the third (3) removes obsolete and sexist terminology at some points of initial scale (Dunlap et al 2000: 425). In contrast to the "dominant social paradigm" (DSP), which upholds human dominance over nature and faith that progress and technology will eventually be capable of 
solving all problems, including an ecological crisis, and views humans as separate from, or and superior to nature, the NEP conceives of environmental concern as endorsement of a new ecological worldview where humans are a part of nature and on limitations to growth (Burn et al.: 2012, 137).

In this article we investigate the environmental worldview of the young people from Kosovo. We examined if these young people held beliefs consistent with the DSP or the NEP. We also compare the children's responses in relation to the different countries. Completing this scale will help create a realistic opinion on the state of the environment among our youth. The research will be used to ascertain, improve and enhance the situation in the field of environmental education at the schools and university in this municipality, and from that in this country.

\section{METHODS}

The following hypothesis was put forward: We expected that the most students from Kosovo (Mitrovica) have a pro-ecological orientation, and there are no clear differences between NEP and DSP views. New Ecological Paradigm Scale, known as NEP Scale (developed by Dunlap et al., 2000) was used in this research. The 15-item revised NEP scale uses a 5-point Likert scale to measure endorsement of an ecological worldview (Table 1). Each item was measured on a scale ranging from 1 to 5: strongly agree (5), agree (4), neither agree or disagree (3), disagree (2), and strongly disagree (1). The NEP score is calculated as the sum of positive responses for each item: strongly agree plus agree. As the directionality of the anthropocentric items was reversed, the NEP score of these items was adjusted. Mean total pro-NEP\% is average NEP score.

Agreement with the eight odd-numbered items indicates pro-NEP orientation, while agreement with the seven even numbered ones indicates pro-DSP orientation. The boundary between a pro-ecological perspective and a human-dominance one is generally held to be a NEP score of 45 (Rideout, et al. 2005). People scoring below 45 tend to be more in favor of the DSP worldview, whereas those with scores higher than 45 tend to be more in favor of the NEP worldview (Van Petegem and A. Blieck, 2006). 
Table 1. Items in revised NEP Scale (Dunlap et al., 2000).

1. We are approaching the limit of the number of people the earth can support

2. Humans have the right to modify the natural environmental to suit their needs

3. When humans disturb interfere with nature it often produces disastrous consequences.

4. Human ingenuity will insure that we do NOT make the earth unlivable.

5. Humans are severely abusing the environment.

6. The earth has plenty of natural resources if we just learn how to develop them.

7. Plants and animals have as much right as humans to exist.

8. The balance of nature is strong enough to cope with the impacts of modern industrial nations.

9. Despite our special abilities humans are still subject to the laws of nature.

10. The so-called "ecological crisis" facing humankind has been greatly exaggerated.

11. The earth is like a spaceship with very limited room and resources.

12. Humans were meant to rule over the rest of nature.

13. The balance of nature is very delicate and easily upset.

14. Humans will eventually learn enough about how nature works to be able to control it.

15. If things continue on their present course, we will soon experience a major ecological catastrophe.

The study involved 330 young people at age 18-20. 150 young people are from secondary schools, and other (180) are from some different faculties at the State University in Mitrovica. 


\section{RESULTS}

Table 2 shows the response frequency distribution in terms of percentage of children choosing each response and the total NEP score.

Table 2. Frequency distributions for the revised NEP scale $(\mathrm{N}=330) *$.

\begin{tabular}{|c|c|c|c|c|c|c|c|c|c|}
\hline \multicolumn{2}{|c|}{ ITEM } & $\begin{array}{l}\text { SD } \\
21\end{array}$ & $\begin{array}{l}\text { D } \\
41\end{array}$ & $\begin{array}{l}\text { Neither } \\
\text { or D } \\
69\end{array}$ & $\begin{array}{l}\text { A A } \\
103\end{array}$ & \multirow{2}{*}{$\begin{array}{l}\text { SA } \\
96 \\
29.1\end{array}$} & \multicolumn{2}{|c|}{ Standard Dev. NEP score } & \multirow{2}{*}{$\begin{array}{l}\% \\
72.80\end{array}$} \\
\hline 1 & $\frac{\mathrm{N}}{\%}$ & & $\begin{array}{l}41 \\
12.4\end{array}$ & & $\begin{array}{l}103 \\
31.2\end{array}$ & & 68.87 & 3.64 & \\
\hline 2 & $\begin{array}{l}\mathrm{N} \\
\%\end{array}$ & $\begin{array}{l}59 \\
17.9\end{array}$ & $\begin{array}{l}86 \\
26.1\end{array}$ & $\begin{array}{l}71 \\
21.5\end{array}$ & $\begin{array}{l}91 \\
27.6\end{array}$ & $\begin{array}{l}23 \\
7.0\end{array}$ & 65.17 & 3.20 & 64.00 \\
\hline 3 & $\begin{array}{l}\mathrm{N} \\
\%\end{array}$ & $\begin{array}{l}11 \\
3.33\end{array}$ & $\begin{array}{l}20 \\
6.10\end{array}$ & $\begin{array}{l}57 \\
17.3\end{array}$ & $\begin{array}{l}120 \\
36.4\end{array}$ & $\begin{array}{l}122 \\
37.00\end{array}$ & 79.50 & 3.98 & 79.60 \\
\hline 4 & $\begin{array}{l}\mathrm{N} \\
\%\end{array}$ & $\begin{array}{l}60 \\
18.2\end{array}$ & $\begin{array}{l}62 \\
18.8\end{array}$ & $\begin{array}{l}76 \\
23.00\end{array}$ & $\begin{array}{l}109 \\
33.0\end{array}$ & $\begin{array}{l}23 \\
7.00\end{array}$ & 66.88 & 3.08 & 61.60 \\
\hline 5 & $\begin{array}{l}\mathrm{N} \\
\%\end{array}$ & $\begin{array}{l}10 \\
3.00\end{array}$ & $\begin{array}{l}15 \\
4.50\end{array}$ & $\begin{array}{l}60 \\
18.20\end{array}$ & $\begin{array}{l}140 \\
42.40\end{array}$ & $\begin{array}{l}105 \\
31.80\end{array}$ & 81.87 & 3.95 & 79.00 \\
\hline 6 & $\begin{array}{l}\mathrm{N} \\
\%\end{array}$ & $\begin{array}{l}69 \\
20.90\end{array}$ & $\begin{array}{l}62 \\
18.80\end{array}$ & $\begin{array}{l}64 \\
19.4\end{array}$ & $\begin{array}{l}92 \\
27.90\end{array}$ & $\begin{array}{l}43 \\
13.00\end{array}$ & 61.80 & 3.07 & 61.40 \\
\hline 7 & $\begin{array}{l}\mathrm{N} \\
\%\end{array}$ & $\begin{array}{l}17 \\
5.20\end{array}$ & $\begin{array}{l}29 \\
8.80\end{array}$ & $\begin{array}{l}81 \\
24.50\end{array}$ & $\begin{array}{l}116 \\
35.20\end{array}$ & $\begin{array}{l}87 \\
26.40\end{array}$ & 70.43 & 3.69 & 73.80 \\
\hline 8 & $\begin{array}{l}\mathrm{N} \\
\%\end{array}$ & $\begin{array}{l}61 \\
18.50\end{array}$ & $\begin{array}{l}72 \\
21.80\end{array}$ & $\begin{array}{l}119 \\
36.10\end{array}$ & $\begin{array}{l}73 \\
22.10\end{array}$ & $\begin{array}{l}5 \\
1.50\end{array}$ & 71.91 & 3.34 & 66.80 \\
\hline 9 & $\begin{array}{l}\mathrm{N} \\
\%\end{array}$ & $\begin{array}{l}11 \\
3.33\end{array}$ & $\begin{array}{l}21 \\
6.4\end{array}$ & $\begin{array}{l}60 \\
18.20\end{array}$ & $\begin{array}{l}138 \\
41.80\end{array}$ & $\begin{array}{l}100 \\
30.3\end{array}$ & 79.79 & 3.89 & 77.80 \\
\hline 10 & $\begin{array}{l}\mathrm{N} \\
\%\end{array}$ & $\begin{array}{l}59 \\
17.90\end{array}$ & $\begin{array}{l}78 \\
23.60\end{array}$ & $\begin{array}{l}89 \\
27.00\end{array}$ & $\begin{array}{l}88 \\
26.70\end{array}$ & $\begin{array}{l}16 \\
4.80\end{array}$ & 66.61 & 3.23 & 64.60 \\
\hline 11 & $\begin{array}{l}\mathrm{N} \\
\%\end{array}$ & $\begin{array}{l}24 \\
7.30\end{array}$ & $\begin{array}{l}38 \\
11.50\end{array}$ & $\begin{array}{l}104 \\
31.50\end{array}$ & $\begin{array}{l}108 \\
32.70\end{array}$ & $\begin{array}{l}56 \\
17.00\end{array}$ & 70.53 & 3.41 & 68.20 \\
\hline 12 & $\begin{array}{l}\mathrm{N} \\
\%\end{array}$ & $\begin{array}{l}77 \\
23.30\end{array}$ & $\begin{array}{l}80 \\
24.2\end{array}$ & $\begin{array}{l}112 \\
33.90\end{array}$ & $\begin{array}{l}56 \\
17.00\end{array}$ & $\begin{array}{l}5 \\
1.50\end{array}$ & 71.23 & 3.51 & 70.20 \\
\hline 13 & $\begin{array}{l}\mathrm{N} \\
\%\end{array}$ & $\begin{array}{l}72 \\
21.80\end{array}$ & $\begin{array}{l}44 \\
13.30\end{array}$ & $\begin{array}{l}62 \\
18.80\end{array}$ & $\begin{array}{l}88 \\
26.70\end{array}$ & $\begin{array}{l}64 \\
19.4\end{array}$ & 61.37 & 3.08 & 61.60 \\
\hline 14 & $\begin{array}{l}\mathrm{N} \\
\%\end{array}$ & $\begin{array}{l}44 \\
13.30\end{array}$ & $\begin{array}{l}70 \\
21.20\end{array}$ & $\begin{array}{l}118 \\
35.80\end{array}$ & $\begin{array}{l}85 \\
25.80\end{array}$ & $\begin{array}{l}13 \\
3.90\end{array}$ & 71.44 & 3.14 & 62.80 \\
\hline 15 & $\begin{array}{l}\mathrm{N} \\
\%\end{array}$ & $\begin{array}{l}14 \\
4.20\end{array}$ & $\begin{array}{l}25 \\
7.60\end{array}$ & $\begin{array}{l}48 \\
14.05\end{array}$ & $\begin{array}{l}102 \\
30.90\end{array}$ & $\begin{array}{l}141 \\
42.70\end{array}$ & 80.11 & 4.00 & 80.00 \\
\hline & total & & & & & & & 3.48 & 69.61 \\
\hline
\end{tabular}

SD- strongly disagree, D- disagree, A- agree, SA- strongly agree

*The NEP score was calculated as the sum of the positive response frequencies for each item:

SA plus A for Pro-NEP items $(1,3,5,7,9,11,13,15)$

D plus SD for the pro-DSP items $(2,4,6,8,10,12,14)$ 
NEP scores were calculated as an average of all scores on the individual scale items. It is generally accepted that a NEP score of 3 is the boundary between an anthropocentric and a proecological worldview (Rideout et al., 2005; Van Petegem and Blieck, 2006). The mean score for the full NEP scale in this study was 3.48, which indicates that ecological attitudes among the samples were more akin to the pro-NEP orientation. The mean score on the seven pro-DSP items is 3.22, ranged from 3.07 (item "The earth has plenty of natural resources if we just learn how to develop them") to 3.51 (item "Humans were meant to rule over the rest of nature"), while mean of the eight pro-NEP items is 3.71, ranged from 3.08 (item "The balance of nature is very delicate and easily upset') to 4.00 (item "If things continue on their present course, we will soon experience a major ecological catastrophe").

Frequency distributions on the Pro-NEP items show that about two thirds of the sample (63.86\%) agreed on these statements, $15.64 \%$ strongly disagree and disagree, and about $20.49 \%$ are undecided. Distributions on the pro-DSP items reveal that about one third $(31.26 \%)$ of the sample agreed with the statements, while there are considerable numbers of disagreeing (40.65\%) and undecided portions of the sample (28.15). There are no clear differences between pro-NEP and pro-DSP views.

The NEP scale items were designed to tap into five hypothesized facets of an ecological worldview. These include the reality of limits to growth $(1,6,11)$, anti-anthropocentrism $(2,7$, $12)$, the fragility of nature's balance $(3,8,13)$, rejection of human exemptionalism, or antiexemptionalism $(4,9,14)$, and the possibility of an eco-crisis $(5,10,15)$ (Dunlap et al.2000).

Anti-exemptionalism: It is based on the idea that the people who accept the New Ecological Paradigm are supposed to reject that human being is exempt from nature and the laws of nature. In the present study, the averages of the items included in this sub-dimension varied between 3.08 and 3.89. About one quarter $(25.67 \%)$ of the answers in this matter contained indecisiveness.

Anti-anthropocentrism: It is the theoretical sub-dimension involving the view that nature exists for meeting the needs of human beings in the first place (items 2 and 12) as well as the view rejecting it (item 7). In this study, the most accepted item was found to be 'plants and animals have as much right as humans to exist' $(\mathrm{M}=3.69)$.

Limits to growth: The New Ecological Paradigm suggests that growth and development have a limit, which is based on the limitedness of the resources in the world. $20.9 \%$ and $31.5 \%$ of the participants said 'unsure' for the item 1 and the item 11 respectively. About $49.7 \%$ of the young 
people agreed with the world-spaceship analogy based on limited resources. In parallel with that, $40.9 \%$ of the young people agreed, 'the earth has plenty of natural resources if we just learn how to develop them'.

Balance of nature: NEP claims the existence of a balance that can be disrupted by human beings. While $73.4 \%$ of the young people agreed with the item 3 suggesting, 'When humans interfere with nature, it often produces disastrous consequences', $46.1 \%$ of the young people agreed with the item 13 stating, 'The balance of nature is very delicate and easily upset'. On the other hand, while $40.3 \%$ of the young people rejected, 'The balance of nature is strong enough to cope with the impacts of modern industrial nations' (a dominant social paradigm perspective), a considerable number of the young people $(36.1 \%)$ were unsure about it.

Eco-crisis: NEP argues that human intervention in nature may lead to negative results at a disaster level that might be described as an eco-crisis. About $74.2 \%$ of the young people strongly agreed and agreed with the item 5, "Humans are severely abusing the environment". $73.6 \%$ of the young people strongly agreed and agree with the item 15, "If things continue on their present course, we will soon experience a major ecological catastrophe".

\section{DISCUSSION AND CONCLUSION}

Developing environmental attitudes is of great importance because there is a statistically significant correlation among attitudes, knowledge, environmental information, and action (for example, see Srbinovski, 2005c). From that, the purpose of this study was to examine ecological attitudes in Kosovo using a theory based psychometric instrument on a simple of young people from Mitrovica city. Overall, the results of the analyses revealed a low endorsement of the NEP among the sample of Kosovo (3.48 or 69.61\%).

The averages of the sub-dimensions varied between 3.28 ("Limits to growth") and 3.73 ("Ecocrisis"). These results might confirm the awareness of the respondents about the harmful consequences of human activity in the biosphere. Awareness of the ecological problems is one of the main pillars on which relate the environmental behaviour of young people. Results from this investigation we might compare, in some point of view, with ones by Atav E. et al. (2015). The averages of the sub-dimensions from this research varied between 2.89 ("Limits to growth") and 3.71 (“Anti-anthropocentrism”).

Bytyci et al. (2017) conducted an investigation of the environmental worldview of the young people from Kosovo using the NEP scale on a sample of 300 young people at age 17-19 (upper 
secondary level) in a secondary school in the city of Malisheva. Similar to the results of this study, the mean total pro-NEP score of $63.32 \%$ indicated a pro-ecological orientation of young people from this community. Srbinovski M. (2016) investigated the impact of gender on the environmental worldview on a sample of Macedonian students. Mean total pro-NEP\% of females and boys are almost identical (56.63\% and 56.80\%, respectively). According to many studies (see: Idrizi, A., Srbinovski, M. \& Jonuzi, I., 2014; Jonuzi, I., 2009, 2012; Srbinovski M., 2001; Ismaili, M., Abazi, A. \& Srbinovski M., 2009; Srbinovski, M., Ismaili, M. \& Abazi, A., 2010; Srbinovski, M., Palmer, J., Ismaili, M., Abazi, A. \& Zenki, V., 2007, and Srbinovski, M., 2019) in the last twenty years approximately $74 \%$ of Macedonian students have demonstrated mainly pro-environmental attitudes.

Compared with other countries such as the United Kingdom (3.31-Pahl et al., 2005), the United States (3.57-Kortenkamp and Moore 2006), Australia (3.96-Blaikie 1992), Turkey (3.50-Erdog an 2009), and Brazil (3.55-Schultz et al., 2005, cit. in Ogunbode, 2013, p. 1486), the findings of this study suggest that ecological attitudes among the sample are more closely characterized by the DSP. Van Petegem P. and Blieck A. (2006), and Boeve-De Pauw J. and Van Petegem P. (2012) in their research investigated the views of young people in Belgium, Vietnam and Zimbabwe, using the revised NEP scale. Belgian children are more favoured or pro-rated by the NEP (NEP score of 63.18\%) than children in Zimbabwe (the NEP average score of $51.44 \%)$ and Vietnam - $(58.9 \%)$ indicating that Belgian children display more pro-ecological concepts than children in Zimbabwe and Vietnam.

In this investigation, we found that there are no clear differences between pro-NEP and proDSP views. The rejection of the DSP by the NEP is a phenomenon that could well only be present in western societies, whereas in less industrialised societies the NEP and DSP could coexist in a holistic paradigm. Caldwell (1990) and Chokor (1993), for example, suggest that indigenous, non-industrialized societies tend to believe in the profound connection between humanity and nature.

There are many factors that create a pro-ecological orientation of young people in a country or region. In any case, the degree of development of a community might be positively correlated to pro-ecological conception. Many studies reveal the relationship between the concern and age. It says that in general, younger generation tends to be more concerned about environmental quality than older generation. Many studies suggest the possible relationships between gender and environmental concerns (cit. in. Economic Commission for Latin America and the Caribbean, 2000). However, this relationship must be treated with caution. As a confirmation 
of this are empirical findings by Srbinovski M. (2016) which suggest that no firm and clear conclusions can be drawn about the effects of gender on (NEP) environmental concern in a sample of Macedonian students. There is a hypothesis that states "environmental concern is positively associated with social class as indicated by education, income and occupational prestige" (Van Liere and Dunlap, 1980). There is a hypothesis that links political ideology and environmental concerns.

Education, of course, plays a key role in the formation of an ecological view of the world. Here we think primarily of students, curricula, textbooks, forms and methods of work, working conditions, teachers and all others involved in the teaching process. Studies focused on finding a 'link' between socio-demographic attributes with environmental concern were successful in identifying some relationships with some social attributes. However, many empirical results are not consistent with these hypotheses. Also, most of these studies are based on experiences from Western culture. Not wanting to speculate, we would just like to emphasize the need to conduct other studies in Kosovo in order to determine the impact of these factors on the ecological view. In conclusion, the results of the analyses revealed a low endorsement of the NEP among the sample of Kosovo young people. The averages of the sub-dimensions varied between 3.08 ("Limits to growth") and 3.73 ("Eco-crisis"). Like as others non-industrialized societies, young people from Kosovo tend to believe in the profound connection between humanity and nature, or there are no clear differences between pro-NEP and pro-DSP views. This study confirms the thesis that environmental worldviews differ across cultures. The mean value of the NEP Scale can be feasibly associated with various variables concerning general environmental attitudes. In order to discover the factors that create a pro-ecological orientation of young people in this country, additional researches are needed.

The present report is a small part of our ongoing studies of environmental beliefs of children in developing countries. It is important to emphasize the limitation of this investigation. First, the sample of individuals is not so great, and secondly, the sample consisted of high school students and students of some faculties of the University of Mitrovica. Therefore, we cannot generalize our results until we and other researchers have conducted further studies with young people from other backgrounds and in other locations. With other words, we believe that future researchers will use much larger samples from different region and cities in Kosovo contexts, as well as social and ethnic background, and educational activities. Despite these constraints, these results give an intriguing insight into the environmental worldview of the young people from the city of Mitrovica in Kosovo. 


\section{REFERENCES}

- Atav Esin, Bahattin Deniz Altunoğlu and Suzan Sönmez (2015). The determination of the environmental attitudes of secondary education students. Procedia - Social and Behavioral Sciences 174: 1391 - 1396.

- Boeve-De Pauw J. \& Van Petegem, P. (2012). Cultural Differences in the Environmental Worldview of Children, International Electronic Journal of Environmental Education, 2 (1): $1-11$.

- Burn, M. Sh., Winter, L. P., Hori, B. \& Silver, N. C. (2012). Gender, Ethnic Identity, and Environmental Concern in Asian Americans and European Americans. Human Ecology Review. 19, 2. www: http://www.fs.fed.us/psw/publications/ winter/ psw_2012_winter001_

- $\quad$ burn.pdf, accessed August 3, 2016.

- Bytyqi Pajtim, Ferdije Zhushi Etemi, Murtezan Ismaili, Mile Srbinovski, Osman Fetoshi \& Albona Shala-Abazi (2017). The Environmental Worldview of Youth in a Secondary School in Kosovo-A Pro NEP Perspective, 5th International Conference on Waste Management, Ecology and Biological Sciences -WMEBS-2017 (pp.: 140-144). Istanbul.

- Caldwell, L. K. (1990). Between two worlds: science, the environmental movement and policy choice. New York. Cambridge University Press.

- Castro, P. (2006). Applying social psychology to the study of environmental concern and environmental worldviews: Contributions from the social representations approach. Journal of Community \& Applied Social Psychology. 16: 247-266.

- Chokor, B. A. (1993). Government policy and environmental protection in the developing world: the example of Nigeria, Environmental Management, 17 (1): 15-30.

- Dunlap, R. E. \& Van Liere, K. D. (1978). The New Environmental Paradigm: A Proposed Measuring Instrument and Preliminary Results". The Journal of Environmental Education. 9 (4): 10-19.

- Dunlap, R. E., Van Liere, K. D., Mertig, A. G. \& Jones, R. E. (2000). Measuring the endorsement of the New Ecological Paradigm: a revised NEP scale" Journal of Social Issues. 56 (3): 425-442. www: http://academic.evergreen. edu/s/smitht/NEP.pdf, accessed August 3, 2016.

- Economic Commission for Latin America and the Caribbean (2000). Role Of Environmental Awareness In Achieving Sustainable Development, LC/R.1961, 23 November, 2000.

- Gillaspy, R. (2015). Environmental Worldviews: Western \& Deep Ecology. www: http://study.com/academy/lesson/ environmental- worldviews-western-deep-ecology, accessed Mars 3, 2017.

- Idrizi, A.; Srbinovski, M. \& Jonuzi, I. (2014). Attitudes of Macedonian High School Students towards the Environment. Procedia-Social and Behavioral Sciences, 159: 636 - 642.

- Iozzi, L. A. (1981). Research in environmental education 1971-1980 (ED 214 762). Columbus, OH: ERIC Clearinghouse for Science, Mathematics and Environmental Education.

- Ismaili, M., Abazi, A. \& Srbinovski M. (2009). Students' attitudes toward the environment. XI Anniversary Scientific Conference with International Attendance (p.: 64), Sofia, Bulgaria: University "St. Kliment Ohridski”.

- Jonuzi, I. (2009). High school students' level of environmental education in the Republic of Macedonia (Unpublished Master thesis). South East European University, Tetovo, Macedonia. 
- Jonuzi, I. (2012). The education system in the function of the advancement of the environment and sustainable development (Unpublished Doctoral dissertation). MIT University, Skopje, Macedonia.

- Maloney, M. P., Ward, M. P. \& Braucht, G. N. (1975). A revised scale for the measurement of ecological attitudes and knowledge. American psychologist. 30 (7): 787-790.

- Ogunbode A. Ch. (2013). The NEP scale: measuring ecological attitudes/worldviews in an

- $\quad$ African context, Environ Dev Sustain, 15: 1477-1494.

- Rideout, B. E., Hushen, K., McGinty, D., Perkins, S. \& Tate, J. (2005). Endorsement of the New Ecological Paradigm in systematic and e-mail samples of college students. Journal of Environmental Education.36 (2): 15-23.

- Srbinovski, M. (2001). Environmental education in primary and secondary schools in the Republic of Macedonia: a biological point of view (Unpublished Doctoral dissertation. Faculty of Natural Sciences and Mathematics, Institute of Biology, Skopje, Macedonia.

- Srbinovski, M. (2005a). Environmental Education, Prosvetno Delo, Skopje.

- Srbinovski, M. (2005b). What is environmental education, Prosvetno Delo, 4: 79-97, 5: 6577.

- Srbinovski, M. (2005c). The relationships between some cognitive and affective environmental educational areas. SEEU (South-East European University) Review 2(2): 223 239.

- Srbinovski, M., Palmer, J., Ismaili, M., Abazi, A. \& Zenki, V. (2007). Environmental Education in the 21st century, III Congress of Ecologists of the Republic of Macedonia, with International Participation (pp.: 520-526), Skopje, Macedonia. Macedonian Ecological Society.

- Srbinovski, M., Ismaili, M. \& Abazi, A. (2010). Environmental education for sustainability across the new Macedonian curriculum. In: Sorial A. and Hong J. (ed.). Proceedings of the 5th International Conference on Environmental Science and Technology (2, 373-380), 1216.07. 2010. Houston: The American Academy of Sciences.

- Srbinovski, M. (2016). Gender Differences in Environmentalism: A Case Study of Macedonian Students", Teaching Innovations, 4: 101-114.

- Srbinovski, M. (2019). Students' level of environmental education in the Republic of North Macedonia. In: Stanisic J. and Radulovic M. (ed.). Abstract book of the 24th International scientific conference "Educational research and school practice". Role of education in modernization of society (pp. 80-81). October 11, 2019. Belgrade, Teacher Education Faculty, University of Belgrade.

- Van Liere, Kent and Riley Dunlap (1980). The social bases of environmental concern: a review of hypothesis, explanations and empirical evidence, Public Opinion Quarterly, 44 (2): 181-197.

- Van Petegem, P. \& Blieck, A. (2006). The environmental worldview of children: a crosscultural perspective. Environmental Education Research, 12 (5): 625-635.

- Weigel, R. \& Weigel, J. (1978). Environmental concern: the development of a measure. Environment and Behavior, 10 (1): 3-15.

- Wiseman, M. \& Bogner, F. X, (2003). A higher-order model of ecological values and its relationship to personality, Personality and Individual Differences. 34(5): 783-794. 